DOI 10.37882/2223-2982.2020.10.06

\title{
СТАНОВЛЕНИЕ НОРМ СЛУЖЕБНОЙ ЭТИКИ ЧИНОВНИКОВ РОССИИ В 1720-1741 ГГ.
}

\section{THE FORMATION OF THE STANDARDS OF SERVICE ETHICS OF RUSSIAN OFFICIALS IN 1720-1741}

\section{E. Borodina}

Summary: The article is devoted to the formation of a code of ethics for civil servants in Russia in the first half of the 18th century. The texts of the General Regulations of 1720 and decrees regulating the behavior of officials were analyzed. The study of the legislation made it possible to conclude that the General Regulations became the first act that included norms that contained the government's ideas about the ideal of a civil servant. Subsequent decrees continued and supplemented the provisions of the Regulation.

Keywords: Russian History, Russian Empire, state service, the General Regulations, code of ethics.
И стория России тесно связана с историей ее государственных институтов и людей, которые трудились в органах власти разных уровней. Не случайно одной из первых исторических школ, появившихся в Российской империи, стала школа историков-государственников, считавших, что жизнь страны определялась именно государством. На данный момент существует значительный пласт историографии, посвященный как реконструкции структуры и основных этапов развития государственных учреждений, так и изучению истории российской бюрократии. Последняя являлась не только важным актором в системе управления, но и движущей силой в периоды крупных преобразований общества.

Несмотря на значительное количество монографических изданий и статей, освещающих различные аспекты жизни аппарата управления, нельзя говорить о снижении интереса ученых к данной проблематике. Это обстоятельство связано, в первую очередь, с многообразием подходов и тем, находящихся в избранном исследовательском поле. Особый интерес историков вызывают периоды становления бюрократии как отдельной социальной общности и серьезных изменений государственной политики по отношению к ней.

XVIII в. считается временем формирования бюрократии нового типа, когда основная работа органов власти оказалась сосредоточена в канцеляриях различных ведомств. Государственные служащие были окончательно поделены на две группы: тех, кто принимал решения
Бородина Елена Васильевна

к.И.н., С.н.С., Институт истории и археологии УрО РАН

(Екатеринбург)

sosnovi-bor@yandex.ru

Аннотация: Статья посвящена вопросу формирования кодекса поведения государственных служащих в России первой половины XVIII в. В ходе исследования были проанализированы тексты Генерального регламента 1720 г. и указов, регулировавших поведение чиновников. Изучение законодательства позволило прийти к выводу, что Генеральный регламент стал первым актом, который включал нормы, содержавшие представления власти 06 идеале государственного служащего. Последующие указы продолжали и дополняли нормы Регламента.

Ключевые слова: история России, Российская империя, государственная служба, Генеральный регламент, этический кодекс.

(члены присутствия), и тех, кто был занят оформлением документации (канцеляристы-делопроизводители). В годы преобразований Петра I теоретическим базисом деятельности государственных учреждений становится концепция камерализма, заложившая идеи рационально организованной бюрократии [2, с. 42, 238; 3, с. 145]. Произошло определение принципов деятельности чиновников, которая была строго регламентирована и документирована. Генеральным регламентом 1720 г. были введены не только новые правила составления документов, но и требования к оснащению канцелярии, часам нахождения на службе, установлены должностные обязанности чиновников.

Генеральный регламент чаще всего рассматривается либо как законодательный памятник, либо как основополагающий документ, определивший порядок организации делопроизводства практически на столетие $[6,11,15,16,17,31]$. Лишь немногие ученые обратили внимание, что закон стал первым документом, где были сформулированы этические основания деятельности бюрократии [11, с. 252-253; 13, с. 111; 34]. В современном мире роль этических кодексов государственных служащих является неоспоримой. По мнению Ю.В. Ирхина, для чиновников Российской Федерации роль «доправового» регулирования до сих пор является одной из ведущих $[14$, c.17].

На сегодняшний день морально-этический облик государственных служащих XVIII в. получил наибольшее 
рассмотрение через призму феномена взяточничества. Данная проблематика нашла всестороннее освещение в трудах историков и специалистов, занимающихся историей государства и права $[8,9,18]$. В частности, она прекрасно исследована применительно к эпохе Петра Великого М.О. Акишиным, Л.М. Балакиревой, Д.А. Рединым, Д.О. Серовым и рядом других ученых [1, 3, 29, 30, 32, 33]. Вопросы казнокрадства и взяточничества были рассмотрены как на примере деятельности глав ведомств и канцелярий, так и с привлечением иллюстративного материала из жизни делопроизводителей. Более поздние случаи злоупотреблений должностным положением служащих в XVIII в. описаны эпизодически Ю.В. Готье, Л.М. Балакиревой, Г.П. Ениным [4, 10, 12]. Значительный вклад в изучение реконструкции правительственной политики в отношении таких правонарушителей внесла Л.Н. Писарькова [20].

Все перечисленные труды позволяют воссоздать картину материального обеспечения российской бюрократии на первых этапах становления, ее формирования как особой социальной группы, а также выявить причины, которые толкали на совершение неподобающих поступков. Тем не менее, кодекс поведения чиновничества, сложившийся в последние годы правления Петра Великого, касался не только взяточничества. Генеральный регламент акцентировал внимание также на этике служебных взаимоотношений и поведении на рабочем месте. Данная сфера проявления государственных служащих еще не нашла должного отражения в исторических исследованиях. Представляется интересным выяснить, какова была позиция государства в вопросе определения норм допустимых и недопустимых действий чиновников после смерти первого российского императора.

В задачи данной статьи вошло, во-первых, выяснение видов желательных и нежелательных поступков государственных служащих, представления о которых транслировались властью посредством создания и обнародования законодательных актов. Во-вторых, - исследование вопроса о преемственности взглядов Петра I на поведение чиновников в период до восшествия на престол Елизаветы Петровны, официально провозгласившей курс на восстановление порядков отца. Данная хронологическая граница во многом условна, но позволяет понять, как протекала адаптация взглядов царя на суть государственной службы, когда власти не занимались открытой декларацией сохранения наследия реформ первой четверти XVIII в.

Представление об основных идеях, положенных в основу этического кодекса чиновничества, можно найти уже в 1 главе Генерального регламента. Она содержит текст присяги, которую каждый из вновь поступавших на службу должен был принести на Евангелии. Должностным лицам следовало быть людьми верными, честными и добрыми, отправлять свои обязанности таким образом, чтобы приносить пользу и благополучие, а «убыток, вред и опасность отвращать». Присяга обязывала хранить тайну всех рассматривавшихся дел, исправлять должность по инструкциям, регламентам и указам «по совести», не поступаться интересами службы ради свойства, корысти, дружбы или вражды [7, с. 73]. Обращается внимание на необходимость быть богобоязненным и верным подданным своего государства.

Текст присяги существенно отличается от тех, что давались в середине XVII в., которые в первую очередь являлись клятвой верности государю и его семье [21, с. 255-256, 308-315]. В Соборном уложении 1649 г. также не имелось точной характеристики морального облика судьи - руководителя приказа - и его подчиненных. Основное внимание было уделено лишь описанию принципов, которых следовало придерживаться вершителям правосудия: блюсти правду, судить по указам, «ни в чем другу не дружити, а недругу не мстити, и никому ни в чем ни для чего не норовити» $[19$, с. 77]. Несмотря на это, законодательные акты конца XVII столетия уже содержат требование о необходимости держать в тайне дела челобитчиков, не показывая их без разрешения руководителей приказов [22, с. 412].

Важным качеством всех государственных служащих Генеральный регламент считал способность верного и скорого исполнения указов [7, с. 75]. Занятым на гражданской службе следовало ответственно подходить к решению порученных дел. При необходимости их требовалось завершать, несмотря на официальное окончание рабочего дня [7, с. 81]. Трудовой этос не позволял брать бумаги домой и выносить решения по челобитным вне стен государственного учреждения [7, с. 84]. В 50 главе Генерального регламента скрупулезно перечисляются нарушения работы с документами, которые подвергались суровому наказанию штрафом, конфискацией имущества, ссылкой на галеру или смертной казнью «по силе прегрешения» [7, с. 100-101].

Само нахождение в канцелярии предполагало соблюдение ряда правил. Закон запрещал входить в присутственное место без почтения, вести в нем праздные разговоры, не относящиеся к рассматриваемому делу, и смеяться. Каждый акт неподобающего поведения карался штрафом в размере 50 рублей [7, с. 85-86]. Кроме того, Генеральный регламент устанавливал чинопочитание: при входе президента в ведомство всем членам учреждения предписывалось вставать. То же следовало делать при выходе. Все доношения президенту также подавались стоя [7, с. 86-87].

Пожалуй, важнейшей для понимания идеального образа чиновника первой четверти XVIII в. является 25 глава «Надзирание на поступки служителей». Она декла- 
рирует, что президентам и вице-президентам коллегий следует обращать внимание на то, чтобы канцеляристы и другие работники учреждения «должность свою знали», а также «каждого к добродетели и достохвальному любочестию побуждали, чтоб безбожного жития не имели, также пития и игры, лжи и обманства удерживали, и чтоб оные в одежде чисто содержались, а во обхождении постоянно и недерзостно поступали» [7, с. 87]. В случае, если государственные служащие не корректировали свое поведение, их могли наказать «отнятием чина» или смещением с должности.

По Генеральному регламенту ошельмованные или понесшие публичное наказание не могли больше занимать свои должности: «ни в какое дело, ниже свидетельство не принимать». По мнению создателей законодательного акта, такие правонарушители не были достойны общества «добрых людей». Лишение чести для чиновника считалось одной из самых страшных кар. Законодатель полагал, что угроза отнятия чести может удержать от совершения серьезных правонарушений и «худых поступков» [7, с. 102].

Нормы последующих глав Генерального регламента также прямо или косвенно говорят о необходимости сохранения чести. Образцом поведения декларируется «надлежащее послушание вышним», следование приговорам и «правам», всеобщие трудолюбие и прилежная работа, а также исключение из обхождения между членами коллегий и иных канцелярий «непристойных поступков» и побоев [7, с. 102-103].

Несмотря на то, что Генеральный регламент был создан для регулирования деятельности коллегий, его нормы стали базисом функционирования всех государственных учреждений страны. По указу от 19 июня 1719 г. произнесение текста присяги из Регламента стало обязательным не только в центральных, но и в региональных органах власти [7, с. 108]. Это повеление было подтверждено в ноябре 1721 г. в связи с титулованием Петра императором [23, с. 452, 453]. В 1724 гг. император еще раз обратил внимание на необходимость соблюдения норм закона, повелев читать его текст во всех ведомствах. Кроме того, указ от 21 января 1724 г. еще раз предписывал соблюдать благочиние в канцеляриях и контоpax [24, с. 205, 214-215].

Изучение законодательства Петра I показывает, что к концу правления монарха сложилась более или менее ясное представление о том, какими качествами следовало обладать представителям бюрократии. Царь уделял много внимания коррекции поведения государственных служащих. Базовым концептом - регулятором их поведения - являлось понятие о чести. Вокруг нее выстраивались другие характеристики: верный, добрый человек, послушный раб и подданный. Любое наруше- ние чести было сопряжено с лишением должности и статуса и сопровождалось другими наказаниями.

Необходимость придерживаться норм Генерального регламента не раз упоминается в наказах и инструкциях должностным лицам последующих лет [24, с. 671-672; 28, с. 276, 300-301]. Кроме того, акцентируется внимание на качествах представителей бюрократии. Так, например, текст присяги ставшего типовым актом для всех инструкций воеводам и губернаторам - Наказа губернаторам, воеводам и их товарищам от 12 сентября 1728 г. - отмечал, что чиновникам следует быть людьми верными и добрыми, послушными рабами и подданными [25, с. 94]. В присягах из наказов Киевскому и Санкт-Петербургскому воеводам, датируемым 1737 г., повторяются те же строки [27, с. 20, 224]. В 1739 г. правительство, озабоченное поисками воевод в Сибирскую губернию, определило, что они должны быть людьми «добрыми, пожиточными и совестными» $[27$, с. 696].

Несмотря на то, что анализ законодательных актов, изданных после смерти первого российского императора, показывает преемственность в установлении норм поведения государственных служащих страны, следует отметить, что наследники Петра мало обращали внимание на эту область регулирования. Лишь в годы правления Анны Иоанновны государство вновь вернулось к идее о необходимости контроля за деятельностью чиновников на рабочих местах. В первой половине 1730$\mathrm{x}$ гг. издается ряд указов, подтверждавших положения Генерального регламента. Их появление было вызвано сложностями в организации текущей деятельности делопроизводителей и членов присутствия Сената и Коммерц-коллегии. Фактически описанные затруднения касались работы всех центральных и региональных органов власти.

Указ от 8 декабря 1733 г., например, цитирует отдельные главы Генерального регламента: 5 и 6 («как в слушании дел поступать»), 18 («о несочинении протоколов» дома), 21 (запрещавшей в коллегиях «непотребные и праздные слова и смех иметь»), 26 (о неотягощении президентов ничем «сверх должности») и 54 (о запрете непристойных поступков, побоев и прочих непотребных вещей). Как можно заметить, большинство из перечисленных глав касалось правил поведения в канцеляриях [26, с. 240-242]. Закон от 10 мая 1734 г. утверждал необходимость чуткого надзора «над секретарями и прочими канцелярскими служителями», таким образом в очередной раз отметив особую роль руководителя ведомства [26, с. 319-320]. Сенатский указ от 7 мая 1740 г. дополнил норму 1734 г.: в обязанности секретарей и обер-секретарей вменялось следить за тем, чтобы служащие неотступно следовали законам [27, с. 109].

В целом законодательные акты второй половины 
царствования императрицы периодически повторяли указы 1733-1734 гг. [26, с. 715-716; 27, с. 975]. Особое внимание уделялось тому, чтобы судьи и канцеляристы вели себя достойно во время судебных разбирательств. Закон от 16 июня 1738 г. прямо запрещал заниматься посторонними делами во время слушаний, которые следовало вести строго в соответствии с указом «О форме суда» 1723 г. [27, с. 538-539]. Этот законодательный акт продолжал и развивал идеи Петра о поведении участников судебного процесса, которые были оформлены указами от 24 октября 1723 г. и 21 января 1724 г. и опирались на 26 и 54 главы Генерального регламента [24, с. 142-143, 214-215].

Указы 1740 г. существенно расширили перечень осуждаемых властью поступков чиновников. В первую очередь они касались представителей региональной администрации, которым запрещалось подписывать крепости и долговые заемные письма, брать векселя, покупать деревни в месте службы, [28, с. 166-168, 223].

Тем не менее, случаи злоупотреблений должностным положением и недобросовестного поведения на рабочем месте повторялись с завидной регулярностью. Так, например, в указе от 16 июня 1740 г. отмечалось, что руководители коллегий, канцелярий и контор, находившихся в Москве, использовали солдат Московского гарнизона для караулов в «домах судейских» [28, с. 160]. Как члены присутствий, так и канцеляристы учреждений часто опаздывали к месту службы или, наоборот, уходили с нее раньше [24, с. 671-672; 26, с. 141, 226-227, 240-242, 319-320, 566-570, 957; 27, с. 69, 793; 28, с. 161]. Встречались и другие нарушения.

Таким образом, анализ содержания нормативных правовых актов, изданных после смерти Петра І, говорит о преемственности политики в отношении вопроса определения правил допустимого и недопустимого поведения государственных служащих. Основой жизни бюрократии стал Генеральный регламент 1720 г. Большинство законов призывают соблюдать его нормы, не предлагая ничего нового взамен. Через указы красной нитью проходит идея «хранения прав» и действий в соответствии с Регламентом и иными инструкциями и законами, утвердившаяся в годы царствования царя.
По мнению Э.Н. Берендтса, в годы правления первого российского императора установилось «раболепное поклонение перед буквой законов», которое способствовало замене чувства законности формализмом [5, с. 44]. С 1722 г. на столах судейских камор утвердились зерцала, куда были вложены базовые для деятельности чиновников законодательные акты [23, с. 656-657]. Все указы грозили штрафами или иными наказаниями за их неисполнение. Членам присутствия и делопроизводителям требовалось действовать строго в соответствии с буквой закона. Идея исправной службы и следования указам являлась осью служебной этики российских бюрократов в течение всего XVIII в.

Последовавшие за изданием Генерального регламента нормативные правовые акты в основном дополняли и подтверждали положения этого закона. Стоит отметить, что в последнее пятилетие правления Петра I таких актов было издано немного. То же можно сказать и о времени правления императриц и императоров, находившихся у власти до 1741 г. Исключение - десятилетие царствования Анны Иоанновны, в которое наблюдается не простое упоминание необходимости соблюдения Генерального регламента, но и расширенно толкуются нормы отдельных глав документа. Более того, указами 1740 г. вводятся новые виды правонарушений, которые в отдельных ситуациях могли быть истолкованы как способ получения взятки.

Изучение нормативных правовых актов позволило прийти к выводу, что в первой половине XVIII в. сложился комплекс представлений об этических основах государственной службы. Тем не менее, нельзя говорить о том, что в имперской России XVIII в. существовал единый кодекс профессиональной этики бюрократа. Характеристика личностных качеств и профессиональных предпочтений, которые следовало культивировать и поддерживать в себе чиновникам, была разбросана между отдельными нормативными актами. Тем не менее, Генеральный регламент стал одним из первых обобщающих документов, вместивших не только перечни должностных обязанностей членов присутствия и делопроизводителей, сведения о структуре канцелярии и порядке ее работы, но и элементарные представления об этических основаниях их деятельности.

\section{ЛИТЕРАТУРА}

1. Акишин М.О. Полицейское государство и сибирское общество. Эпоха Петра Великого. Новосибирск: Автор, 1996. 223 с.

2. Анисимов Е.В. Время петровских реформ. XVIII век, 1-я четверть. Л.: Лениздат, 1989. 495 [1] с.

3. Балакирева Л.М. Бюрократические принципы в деятельности петровских судебных органов: дело «о пограблении пензенской казны» в муромском лесу (1721-1726 гг.) // Сообщения Муромского музея - 2012: Материалы отчетной конференции МИХМ. Владимир, 2014. С. 145-170.

4. Балакирева Л.М. «0т которого их несмотрения и упущения... казне явился хищник (дело канцеляриста Юстиц-коллегии И. Редина 1727-1731 годов) // Вестник Рязанского государственного университета им. С.А. Есенина. 2017. № 3 (56). С. $7-17$. 
5. Берендтс Э.Н. 0 прошлом и настоящем русской администрации (записка, составленная в декабре 1903 года). СПб.: Типография М.М. Стасюлевича, 1913. VII, $280 \mathrm{c}$.

6. Воскресенский Н.А. Петр Великий как законодатель. Исследование законодательного процесса в России в эпоху реформ первой четверти XVIII века. М.: Новое литературное обозрение, 2017. 637 [2] с.

7. Генеральный регламент // Памятники русского права. Вып. 8. М.: Государственное издательство юридической литературы, 1961. С. $72-121$.

8. Голованова Е.И. Правовые основы борьбы с коррупцией в России в XVI - XIX вв.: Историко-правовое исследование: диссертация ... канд. юр. наук. М., 2002. $187 \mathrm{C}$.

9. Голосенко И.А. Феномен «русской взятки»: очерки истории отечественной социологии чиновничества // Журнал социологии и социальной антропологии. 1999. № 3. T. 2. С. 101-116.

10. Готье Ю.В. История областного управления в России от Петра I до Екатерины II. Т. 1. Реформа 1727 года. Областное деление и областные учреждения 1727-1775 гг. М.: Типография Г. Лисснера и Д. Совко, 1913. 472 с.

11. Емышева Е.М. Генеральный регламент 1720 г. как опыт создания организационного документа // История и архивы. 2008. № 8. С. 248 -261.

12. Енин Г.П. Воеводское праздничное кормление в начале 60-х годов XVIII в. // Вспомогательные исторические дисциплины. СПб.: Дмитрий Буланин, 1994. T. XXV. C. 103-116.

13. Законодательство Петра І. М.: Юридическая литература, 1997. 880 с.

14. Ирхин Ю.В. Этические кодексы в современной государственной службе // Социология власти. 2011. № 4. С. 13-24.

15. Литвак Б.Г. О закономерностях эволюции делопроизводственной документации в XVIII-XIX вв. (К постановке вопроса) // Проблемы источниковедения истории СССР и специальных исторических дисциплин. Статьи и материалы. М.: Наука, 1984. С. 48-55.

16. Лукашевич А.А. К истории делопроизводственной документации России XVIII В. // Отечественные архивы. 2004. № 4. С. 12-18.

17. Митяев К.Г. История и организация делопроизводства в СССР: учебное пособие. М.: Министерство высшего образования СССР; МГИАИ, 1959.360 с.

18. Оболонский А.В. Бюрократия и государство: Очерки. М.: ИГПАН, 1996. 67 с.

19. Памятники русского права. Вып. 6: Соборное уложение царя Алексея Михайловича 1649 г. М.: Государственное издательство юридической литературы, 1957. 503 c.

20. Писарькова Л.Ф. Государственное управление в России с конца XVII до конца XVIII века: Эволюция бюрократической системы. М.: «Российская политическая энциклопедия» (РОССПЭН), 2007. 743 с.

21. Полное собрание законов Российской Империи с 1649 года. Т. І. 1649-1675. СПб.: Типография ІІ Отделения Собственной Его Императорского Величества канцелярии, 1830. 1044 с.

22. Полное собрание законов Российской империи, с 1649 года. Т. III. 1689-1699. СПб.: Типография II Отделения Собственной Его Императорского Величества канцелярии, 1830.691 с.

23. Полное собрание законов Российской империи, с 1649 года. T. VI. 1720-1722. СПб.: Типография II 0тделения Собственной Его Императорского Величества канцелярии, 1830.818 с.

24. Полное собрание законов Российской империи, с 1649 года. Т. VII. 1723-1727. СПб.: Типография II Отделения Собственной Его Императорского Величества канцелярии, 1830.925 с.

25. Полное собрание законов Российской империи с 1649 года. Т. VIII. 1728-1732. СПб.: Типография II Отделения Собственной Его Императорского Величества канцелярии, 1830. 1018 с.

26. Полное собрание законов Российской империи, с 1649 года. Т. ІХ. 1733-1736. СПб.: Типография ІІ Отделения Собственной Его Императорского Величества Канцелярии, 1830. 1025 c.

27. Полное собрание законов Российской империи с 1649 года. Т. Х. 1737-1739. СПб.: Типография ІІ Отделения Собственной Его Императорского Величества канцелярии, $1830.997 \mathrm{c}$.

28. Полное собрание законов Российской империи с 1649 года. Т. ХІ. 1740-1743. СПб.: Типография II Отделения Собственной Его Императорского Величества канцелярии, 1830.990 с.

29. Редин Д.А. Административные структуры и бюрократия Урала в эпоху петровских реформ (западные уезды Сибирской губернии в 1711 - 1727 гг.). Екатеринбург: Волот, 2007.606 c.

30. Редин Д.А. Этюды по русской истории Нового времени (административный и социальный аспекты). Екатеринбург: Издательство Уральского университета, 2019. $279 \mathrm{c}$.

31. Русакова С.В. Законодательное регулирование в учреждениях XVIII в. // Делопроизводство. 2005. № 2. С. 81-87.

32. Серов Д., Федоров А. Следователи Петра Великого. М.: Молодая гвардия, 2018. 347 с.

33. Серов Д.О. Строители империи: Очерки государственной и криминальной деятельности сподвижников Петра І. Новосибирск: Изд-во Новосибирского гос. ун-та, 1996. 262 с.

34. Шободоева А.В. Государственная гражданская служба России XVIII века и особенности ее правового регулирования // Известия иркутской государственной экономической академии (Байкальский государственный университет экономики и права). 2013. №1. URL: https://cyberleninka.ru/article/n/ gosudarstvennaya-grazhdanskaya-sluzhba-rossii-xviii-veka-i-osobennosti-ee-pravovogo-regulirovaniya (дата обращения: 27.08.2020).

(с) Бородина Елена Васильевна (sosnovi-bor@yandex.ru) 